\title{
Pelatihan Kerja dan Pengetahuan, dan Kompensasi Karyawan Terhadap Produktivitas Kerja Dampaknya Pada Kinerja Karyawan PT. Hamita Utama Karsa di Musi Banyuasin
}

\author{
Mardiana Puspa Sari \\ Universitas Muhammadiyah Palembang \\ Email: mardianapuspasari165@gmail.com \\ Wani Fitriah \\ Universitas Muhammadiyah Palembang \\ Email: wanifitriahump@yahoo.co.id \\ Ade Putri Kusdina \\ Universitas Muhammadiyah Palembang \\ Email: adeputri@gmail.com
}

\begin{abstract}
This study entitled, Job Training and Knowledge, and Employee Compensation for Work Productivity Impact on Employee Performance of PT. Hamita Utama Karsa in Musi Banyuasin. Productivity is a measure of productive efficiency, a comparison between output and input. Input is often limited by labor, while output is measured in terms of physical units, form, and value. Factors that can increase employee productivity are job training and knowledge, and compensation. It is this productivity that can ultimately improve employee performance.

The purpose of this research study, namely to determine the first effect, Job Training and Knowledge of work productivity. Second, Job Training and Knowledge of employee performance. Third, Employee Compensation for work productivity. Fourth, Employee Compensation for employee performance. Fifth, work productivity has an impact on employee performance at PT Hamita Utama Karsa Musi Banyuasin. The analysis technique used in this research is Structural Equation Model (SEM) analysis. Analysis shows direct and indirect relationships. Qualitative data from the recapitulation of respondents' answers was quantified, so that it could be calculated statistically. This study concludes first, Training and Knowledge have a significant effect on Productivity. Second, Training and Knowledge have a positive and significant impact on Employee Performance. Third, compensation has a positive and significant effect on productivity. Fourth, Compensation has a positive and significant effect on Employee Performance. Fifth, Productivity has a positive and significant effect on Employee Performance.
\end{abstract}

Keywords: training and knowledge, compensation, productivity and performance.

\begin{abstract}
Abstrak
Penelitian ini berjudul, Pelatihan Kerja dan Pengetahuan, dan Kompensasi Karyawan untuk Dampak Produktivitas Kerja terhadap Kinerja Karyawan PT. Hamita Utama Karsa di Musi Banyuasin. Produktivitas adalah ukuran efisiensi produktif, perbandingan antara output dan input. Input sering dibatasi oleh tenaga kerja, sedangkan output diukur dalam satuan fisik, bentuk, dan nilai. Faktor-faktor yang dapat meningkatkan produktivitas karyawan adalah pelatihan kerja dan pengetahuan, dan kompensasi. Produktivitas inilah yang pada akhirnya dapat meningkatkan kinerja karyawan. Tujuan penelitian penelitian ini untuk mengetahui pengaruh pertama, Pelatihan Kerja dan Pengetahuan produktivitas kerja. Kedua, Pelatihan Kerja dan Pengetahuan tentang kinerja karyawan. Ketiga, Kompensasi Karyawan untuk produktivitas kerja. Keempat, Kompensasi Karyawan untuk kinerja karyawan. Kelima, produktivitas kerja berdampak pada kinerja karyawan di PT Hamita Utama Karsa Musi Banyuasin Teknik analisis yang digunakan dalam penelitian ini adalah analisis Structural Equation Model (SEM). Analisis menunjukkan hubungan langsung dan tidak langsung. Data kualitatif dari rekapitulasi jawaban responden dikuantifikasi, sehingga dapat dihitung secara statistik. Penelitian ini menyimpulkan pertama, Pelatihan dan Pengetahuan memiliki pengaruh signifikan terhadap Produktivitas. Kedua, Pelatihan dan Pengetahuan memiliki dampak positif dan signifikan terhadap Kinerja Karyawan. Ketiga, kompensasi memiliki pengaruh positif dan signifikan terhadap produktivitas. Keempat, Kompensasi berpengaruh positif dan signifikan terhadap Kinerja Karyawan. Kelima, Produktivitas memiliki pengaruh positif dan signifikan terhadap Kinerja Karyawan.
\end{abstract}

Kata kunci: pelatihan dan pengetahuan, kompensasi, produktivitas dan kinerja. 


\section{Pendahuluan}

Pada pratiknya tidak selamanya bahwa kinerja karyawan dalam kondisi seperti yang di inginkan baik oleh karyawan itu sendiri ataupun organisasi jadi atasan harus menyadari adanya perbedaan kinerja antara karyawan yang berada di bawah pengawasannya, sekalipun karyawan berada di tempat yang sama namun produktivitas mereka tidak selalu sama perbedaan ini mengakibatkan kinerja seseorang tidak selalu sama (Kasmir, 2017:189).

Produktivitas adalah ukuran efesiensi produktif, bandingan antara hasil keluaran dan masukan. Masukan sering dibatasi dengan tenaga kerja, Sedangkan keluaran diukur dalam ke-satuan fisik, bentuk, dan nilai (Edy Sutrisno, 2015:99). Salah satu faktor yang dapat meningkatkan produktivitas kerja karyawan Menurut Simanjuntak dalam Edy sutrisno, (2015:103) adalah Pelatihan. Pelatihan kerja yang di maksudkan untuk melengkapi karyawan dengan keterampilan dan cara cara yang tepat untuk menggunakan peralatan kerja maka dari itu, pelatihan kerja di perlukan bukan saja sebagai pelengkap akan tetapi sekaligus untuk memberikan dasar-dasar pengetahuan karena dengan latihan berarti para karyawan belajar mengerjakan sesuatu dengan benar dan tepat, serta dapat memperkecil atau meninggalkan kesalahan kesalahan yang pernah di lakukan. Apabila dalam suatu perusahaan tidak ada pelatihan maka hal tersebut akan berdampak langsung terhadap produktivitas kerja karyawan. Pelatihan merupakan proses untuk membentuk dan membekali karyawan dengan menambah keahlian, kemampuan, pengetahuan, dan prilakunya (Kasmir, 2017:126). Untuk meningkatkan produktivitas agar mendapatkan hasil kerja yang baik maka karyawan harus mempunyai keahlian, kemampuan, dan pengetahuan dalam bidang pekerjaannya masingmasing.

Bagi mereka yang memiliki kinerja terbaik, tentu akan mendapatkan kompensasi yang lebih baik di bandingan dengan karyawan yang kurang memiliki kemampuan untuk menghasilkan kinerja maka karyawan akan termotivasi untuk memiliki kemampuan yang baik jika kompensasi dalam perusahaan di berikan dengan efektif (Kasmir, 2017:233). Kompensasi adalah semua pendapatan yang berbentuk uang, barang langsung atau tidak langsung yang di terima karyawan sebagai imbalan atas jasa yang di berikan kepada perusahaan (Hasibuan, 2014:118). Pemberian kompensasi yang benar akan berpengaruh pada produktivitas kerja karyawan dan kinerja karena dengan kompensasi karyawan akan terus meningkatkan kualitas kerjanya yang ahirnya kan meingkat pula prestasi kerjanya dan produktivitasnya.

PT. Hamita Utama Karsa di Musi Banyuasin adalah perusahaan Agrobisnis yang bergerak di bidang pengolahan minyak kelapa sawit mentah atau Crude Palm Oil (CPO). PT Hamita Utama Karsa merupakan anak cabang dari PT. Indonusa Agro Mulia Jambi. Pada PT. Hamita Utama Karsa memiliki pabrik untuk mengelola buah kelapa sawit menjadi minyak mentah, serta bagian kantor untuk pendataan. Kurangnya keahlian bekerja pada bagian pabrik mebuat pengelolaan buah kelapa sawit menjadi minyak mentah tidak efisien, serta kurangnya tunjangan selama bekerja di perusahaan akan berpengaruh terhadap menurunnya produktivitas Perusahaan. Berikut data hasil produksi Curd Palm Oil (CPO) PT Hamita Utama Karsa Musi Banyuasin 5 (lima) tahun terakhir 
MBIA
p-ISSN 2086-5090, e-ISSN: 2655-8262
Vol. 19, No. 1, April 2020

Tabel .1 Data Hasil Produksi CPO

\begin{tabular}{|c|c|c|c|}
\hline Tahun & $\begin{array}{c}\text { Target Produksi } \\
\text { Cpo (L) }\end{array}$ & $\begin{array}{c}\text { Hasil Produksi } \\
\text { Cpo (L) }\end{array}$ & Persentase (\%) \\
\hline 2013 & 106.860 & 81.400 & 76 \\
\hline 2014 & 220.100 & 180.302 & 82 \\
\hline 2015 & 466.260 & 376.900 & 81 \\
\hline 2016 & 707.970 & 419.383 & 59 \\
\hline 2017 & 1.074 .400 & 518.180 & 48 \\
\hline
\end{tabular}

Sumber : Data Produksi PT. Hamita Utama Karsa di Musi Banyuasin, 2018

Data Produksi PT. Hamita Utama Karsa yang diolah 2018, peneliti mendapat keterangan bahwa hasil produksi pertahunnya tidak pernah mencapai target yang di tetapkan oleh perusahaan, dapat dilihat pada tahun 2013 hanya mendapatkan hasil produksi 81.400 Liter CPO dan pada tahun 2017 hasil produksi juga idak mencapai target yang telah di tentukan oleh perusahaan. Hal ini di karnakan buah tidak sepenuhnya di produksi, sisa buah yang tidak terproduksi juga akan membusuk dalam beberapa minggu dan tidak bisa dioalah sehingga menimbulkan kerugian pada perusahaan, hal ini membuktikan bahwa produktivitas kerja PT. Hamita Utama Karsa tidak Optimal dan berdampak pada menurunnya kinerja karyawan.

Hasil produksi tidak pernah mencapai target yang telah di tetapkan perusahaan di karnakan kurangnya keahlian dan pengetahuan karyawan dalam bekerja, PT. Hamita Utama Karsa hanya mengadakan Program pelatihan On The Job untuk mengendalikan mesin di pabrik, pemasangan dan pelepasan rantai crane dan perebusan buah kelapa sawit, dengan waktu 3 hari pada jam kerja oleh karyawan yang kurang profesional dalam bidang kerjanya tersebut. Pada bagian kantor juga hanya mengandalkan pelatihan on the job untuk pengelola data hasil panen buah sawit, hal ini membuat karyawan pada bagian kantor masih menggunakan system manual untuk pendataan buah sawit perharinya karena kurang mengerti dengan system aplikasi computer. PT. Hamita Utama Karsa kurang memberikan materi pelatihan tentang job dsscriptions yang lebih efektif diadakan di balai khusus untuk karyawan bagian pabrik dan bagian kantor, serta tidak adanya simulasi untuk mengetahui layak atau tidaknya karyawan dalam melakukan pekerjaan di bidang masing-masing. kurangnya pelatihan pada perusahaan tersebut membuat karyawan kurang mengerti dalam bidang pekerjaannya dan cenderung lambat dalam bekerja, hal ini membuat hasil produksi pada PT. Hamita Utama Karsa tidak pernah mencapai target.

Pada PT. Hamita Utama Karsa Kesenjangan juga terjadi karena kurangnya kompensasi, kurangnya insentif yang di berikan perusahaan kepada karyawan yang bekerja lembur membuat karyawan kurang merasa di berdayakan dan kurang termotivasi untuk berkerja, karyawan hanya mengandalkan gaji pokok tanpa adanya insentif yang berikan kepada karyawan yang memiliki prestasi, hanya sebagian karyawan yang di berikan tunjangan kesehatan dan tunjangan asuransi jiwa menyebabkan kurangnya rasa aman dalam bekerja di PT Hamita Utama Karsa. Karyawan PT Hamita Utama Karsa akan mengalami kebosanan dalam bekerja. Minimnya penghargaan eksterinstik dan insterinstik seperti karyawisata, dan jaminan sosial yang di berikan perusahaan kepada karyawan membuat karyawan akan mengalami kebosanan dalam bekerja hal ini menghambat produktivitas dan kinerja karyawan tidak optimal. 


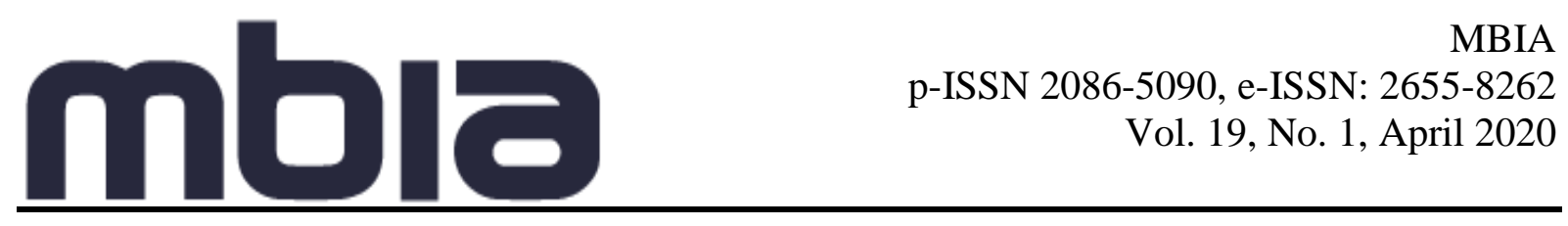

Tabel .2 Data Panen Buah Sawit

\begin{tabular}{|l|l|l|l|}
\hline Tahun & $\begin{array}{l}\text { Hasil Panen } \\
\text { Buah Sawit } \\
\text { (Ton) }\end{array}$ & $\begin{array}{l}\text { Buah Sawit } \\
\text { Yang Diolah } \\
\text { (Ton) }\end{array}$ & Persentase (\%) \\
\hline 2013 & 593,662 & 452,070 & 76 \\
\hline 2014 & $1.222,558$ & $1.112,790$ & 91 \\
\hline 2015 & $2.590,327$ & $2.093,432$ & 81 \\
\hline 2016 & $3.933,156$ & $2.768,790$ & 70 \\
\hline 2017 & $5.968,850$ & $3.989,845$ & 66 \\
\hline
\end{tabular}

Sumber : Data Produksi PT. Hamita Utama Karsa di Musi Banyuasin, 2018

Kurangnya pelatihan kerja dan kompensasi yang belum mencukupi kebutuhan karyawan berdampak pada produktivitas mengakibatkan karyawan kurang memiliki kemampuan dalam bekerja pengembangan diri yang sangat minim, dan Efesiensi dalam perusahaan menurun. Di buktikan dengan data produktivitas pada PT. Hamita Utama Karsa, Perbandingan antara hasil yang dicapai dengan keseluruhan sumber daya yang akan di gunakan tidak sesuai sehingga dapat di nyatakan tidak efisien. Realisasi yang tidak pernah mencapai target di karnakan hasil panen buah sawit pertahun tidak semua diolah oleh karyawan mengakibatkan CPO yang di hasilkan tidak sesuai dengan target. Hal ini merupakan aspek produktivitas yang memberikan pengaruh yang cukup signifikan bagi kinerja karyawan.

Produktivitas yang menurun akan mempengaruhi kinerja karyawan pada PT. Hamita Utama Karsa dan akan berdampak pada tujuan dan standard yang belum tercapai serta kompetensi yang dimiliki karyawan untuk menjalankan pekerjaan sangat kurang, pelatihan kerja yang minim dan Kompensasi yang perusahaan berikan belum mencukupi kebutuhan karyawan akan berdampak pada kinerja yang tidak optimal.

\section{Landasan Teori}

\subsection{Produktivitas Karyawan}

Menurut Belcher, dalam Wibowo (2016:3) Secara konseptual, produktivitas adalan hubungan antara keluaran atau hasil organisasi dengan masukan yang di perlukan. Produktivitas dapat di kuantikasi dengan membagi keluaran dengan masukan. Menaikan produktivitas dapat di lakukan dengan memperbaiki rasio produktivitas, dengan menghasilkan lebih banyak keluaran atau output yang lebih baik dengan tingkat sumber daya tertentu. Menurut Sutrisno (2015:99), Produktivitas secara umum diartikan sebagai hubungan antara keluaran (barangbarang atau jasa) dengan masukan (tenaga kerja, bahan, uang). Produktivitas adalah ukuran efesiensi produktif. Bandingan antara hasil keluaran dan masukan. Masukan sering dibatasi dengan tenaga kerja. Sedangkan keluaran diukur dalam ke-satuan fisik, bentuk, dan nilai.

Menurut Edy Sutrisno (2015: 104) Produktivitas merupakan hal yang sangat penting bagi para karyawan yang ada di perusahaan. Dengan adanya produktivitas kerja di harapkan pekerjaan akan terlaksana secara efisien dan efektif. Sehingga ini semua ahirnya sangat di perlukan dalam pencapaian tujuan yang telah di tetapkan. Untuk mengukur produktivitas kerja, di perlukan suatu indikator sebagai berikut :

a) Kemampuan, b) Meningkatkan hasil yang di capai, c) Semangat Kerja, d) Pengembangan diri, e) Mutu, f) Efisiensi. 
Terdapat perbedaan pada variabel dependen dan independen yang digunakan pada beberapa penelitian sebelumnya, yaitu penelitian Aliya (2019) menunjukkan hasil penelitian bahwa Secara parsial variabel pendidikan tidak terdapat pengaruh terhadap produktivitas kerja karyawan. Sedangkan variabel pelatihan secara parsial memiliki pengaruh terhadap produktivitas kerja karyawan. Secara simultan, kedua variabel pendidikan dan pelatihan berpengaruh terhadap produktivitas kerja karyawan. Selanjutnya pada penelitian Devi Apriani (2019), secara simultan terdapat pengaruh antara variabel disiplin kerja dan pelatihan terhadap prestasi kerja karyawan.

\subsection{Kinerja Karyawan}

Menurut Edy Sutrisno (2009 : 172)Kinerja karyawan adalah hasil kerja karyawan dilihat dari aspek kualitas, kuantitas, waktu kerja, dan kerja sama untuk mencapai tujuan yang sudah ditetapkan oleh organisasi. Menurut Wibowo (2016: 2) Kinerja adalah nilai serangkaian perilaku pekerja yang memberikan kontribusi baik secara positif maupun negatif, pada penyelesaian tujuan organisasi. Menurut Soekidjo Notoadmodjo (2015 :124) Kinerja karyawan adalah kemampuan yang dicapai oleh seseorang karyawan selama periode waktu tertentu pada bidang pekerjaan tertentu sesuai dengan tugas dan fungsinya.

Menurut Wibowo ( 2016 : 86 ), faktor - faktor yang mempengaruhi kinerja karyawan sebagai berikut :

a) Tujuan, b) Standar, c) Umpan balik.

\subsection{Pelatihan Kerja}

Menurut Kasmir (2017:126) Pelatihan merupakan proses unuk membentuk dan membekali karyawan dengan menambah keahlian, kemampuan, pengetahuan, dan prilakunya.Wibowo (2015:170) Pelatihan (training) merupakan investasi yang penting bagi sumber daya manusia, pelatihan melibatkan segenap sumber daya manusia untuk mendapatkan pengetahuan dan keterampilan pembelajaran sehingga mereka segera dapat menggunakannya dalam suatu pekerjaan. Widodo (2015: 82) Pelatihan merupakan serangkaian aktivitas individu dalam meningkatkan keahlian dan pengetahuan secara sistematis sehingga mampu memiliki kinerja yang profesional di bidangnya. Pelatihan adalah proses pembelajaran yang memungkinkan pegawai melaksanakan pekerjaan yang sekarang sesuai dengan standard.

Menurut Andre E. Sikula dalam Mangkunegara (2015:53) Mengemukakan beberapa indikator dalam pelatihan sebagai berikut:

a) On The Job

b) Vestibule atau Balai

c) Metode demonstrasi dan contoh

d) Simulasi

e) Apprenticeship

f) Metode Ruang Kelas

\subsection{Kompensasi Karyawan}

Menurut Kasmir (2017:233) Kompensasi merupakan balas jasa yang di berikan perusahaan kepada karyawannnya, baik bersifat keuangan maupun non keuangan. Adapun pengertian kompensasi menurut Dr. Omar Hendro (2018:160) dari prespektif karyawan, khususnya, kompensasi merupakan salah satu aspek yang paling terlihat dari manajemen sumber daya manusia internasional. 
Menurut Drs. Malayu Hasibuan (2014:118) Kompensasi semua pendapatan yang berbentuk uang, barang langsung atau tidak langsung yang di terima karyawan sebagai imbalan atas jasa yang di berikan kepada perusahaan.

Menurut Afandi (2018:194-195) terdapat beberapa indikator kompensasi antara lain :

a) Upah dan Gaji, b) Insentif , c) Tunjangan , d) Fasilitas , e) Penghargaan.

\section{Metode Penelitian}

Metode pengumpulan data yang digunakan dalam penelitian ini adalah teknik kuesioner yang berhubungan dengan indikator-indikator yang digunakan. Populasi adalah wilayah generalisasi yang terdiri atas obyek/subyek yang mempunyai kuantitas dan karakteristik tertentu yang di tetapkan peneliti untuk di pelajari kemudian di tarik kesimpulannya (Sugiyono, 2016:148). Merujuk pada definisi tersebut, populasi pada penelitian ini sebanyak 127 karyawan yang merupakan seluruh karyawan tetap PT. Hamita Utama Karsa di Musi Banyuasin.

Sampel dalam SEM yang sesuai adalah antara 100-200 sampel untuk teknik maximum likehood estimation dan menyarankan agar ukuran sampel minimum adalah sebanyak 5-10 kali jumlah parameter yang diestimasi. Dalam penelitian ini, terdapat 20 indikator (parameter yang diestimasi), maka sampel yang digunakan adalah antara 100-200 sampel. Jadi sampel yang diolah dalam penelitian ini adalah : 4 variabel $\mathrm{x} 3$ indikator $\mathrm{x} 9$ (minimum jumlah parameter yang di estimasi) $=108$ sampel. Adapun perician populasi dan sample sebagai berikut :

Tabel 3. Jumlah Populasi dan Sampel

\begin{tabular}{|l|c|l|}
\hline Tingkat Pendidikan Karyawan Tetap & Populasi & Sample \\
\hline SMA & 61 & $(108 / 127) \times 61=52$ \\
\hline D3 & 23 & $(108 / 127) \times 23=20$ \\
\hline S1 & 43 & $(108 / 127) \times 43=36$ \\
\hline Total & 127 & 108 \\
\hline
\end{tabular}

Sumber, Adm PT. Hamita Utama Karsa Musi Banyuasin, 2018

Adapun tehnik sampling yang di gunakan dalam penelitian ini adalah probality sampling dengan metode Propotionate Stratified random sampling. Propotionate Stratified random sampling adalah tehnik sampling yang di gunakan apabila populasi mempunyai anggota atau unsur yang tidak homogeny dan tidak berstrata secara proposional (Sugiyono 2016:93).

Teknik analisis yang digunakan dalam penelitian ini adalah analisis Structural Equation Model (SEM). Hengky Latan (2012:5) analisis data digunakan model persamaan Structural Equation Modelling (SEM) merupakan suatu teknik analisis multivariate generasi kedua yang menggabungkan antara analisis faktor dan analisis jalur sehingga memungkinkan peneliti untuk menguji dan mengestimasi secara simultan hubungan antara multivate exogenous dan endogenous variabel dengan banyak indikator. Untuk mengestimasi parameter model, dirumuskan persamaan model pengukuran dan persamaan model sruktural sebagai berikut: 
Persamaan model pengukuran

1) Pengukuran peubah pelatihan kerja: $\quad X 1.1=\lambda 1 \quad X 1+\delta 1$

2) Pengukuran peubah Kompensasi Karyawan : $X 1.1=\lambda 6 \mathrm{X} 1+\delta 6$

3) Pengukuran peubah produktivitas karyawaan : $\mathrm{Y} 1-1=\lambda 12 \mathrm{Y} 1+\epsilon 1$

4) Pengukuran peubah Kinerja Karyawan : Y1.1= $\lambda 17$ Y1 $+\epsilon 6$

Persamaan model struktural

1) Model Produktivitas karyawan: $\mathrm{Y} 1=\gamma 1 \mathrm{X} 1+\gamma 2 \mathrm{X} 2+\delta 1$

2) Model kinerja karyawan :

$\mathrm{Y} 2=\gamma 3 \mathrm{X} 1+\gamma 4 \mathrm{X} 2+\beta 1 \mathrm{Y} 1+\delta 2$ Keterangan: $\lambda=$ Hubungan langsung variabel eksogen atau endogen terhadap indikatornya;

$\varepsilon=$ Measurement Error dari variabel endogen;

$\delta=$ Measurement Error dari variabel eksogen;

$\gamma=$ Hubungan langsung variabel eksogen dengan endogen;

$\beta=$ Hubungan langsung variabel endogen dengan endogen.

Untuk menguji model yang telah dirumuskan menggunakan ketentuan pengujian kesesuaian model.

Efek Dekomposisi (Pengaruh Total dan Pengaruh Tak Langsung), efek dekomposisi terjadi berdasarkan pembentukan diagram jalur yang bisa dipertanggungjawabkan secara teori. Pengaruh antara konstrak laten dibagi berdasarkan kompleksitas hubungan variabel, yaitu:

a. pengaruh langsung (direct effects)

b. pengaruh tak langsung (indirect effects)

c. pengaruh total (total effects)

Pengaruh total merupakan penjumlahan dari pengaruh langsung dan pengaruh tak langsung, sedangkan pengaruh tak langsung adalah perkalian dari semua pengaruh langsung yang dilewati (variabel eksogen menuju variabel endogen/variabel endogen). Pada software LISREL, pengaruh langsung diperoleh dari nilai output completely standardized solution, sedangkan efek dekomposisi diperoleh dari nilai output standardized total and indirect effects. Pengaruh variabel Pelatihan Kerja terhadap variabel Produktivitas karyawan, yaitu:

(a) pengaruh langsung Pelatihan Kerja terhadap produktivitas kerja $=\gamma 3$

(b) pengaruh tak langsung Pelatihan Kerja terhadap produktivitas kerja $=$ (pengaruh langsung Pelatihan Kerja terhadap kinerja karyawan) + (pengaruh langsung Pelatihan Kerja terhadap produktivitas kerja) $=\gamma 1+\beta 1$

(c) Pengaruh total Pelatihan Kerja terhadap produktivitas kerja = (pengaruh langsung Pelatihan Kerja terhadap produktivitas kerja) + (pen garuh tak langsung Pelatihan Kerja terhadap produktivitas kerja) $=\gamma 3+\gamma 1+\beta 1$ 
Gambar .1: Kerangka Pemikiran

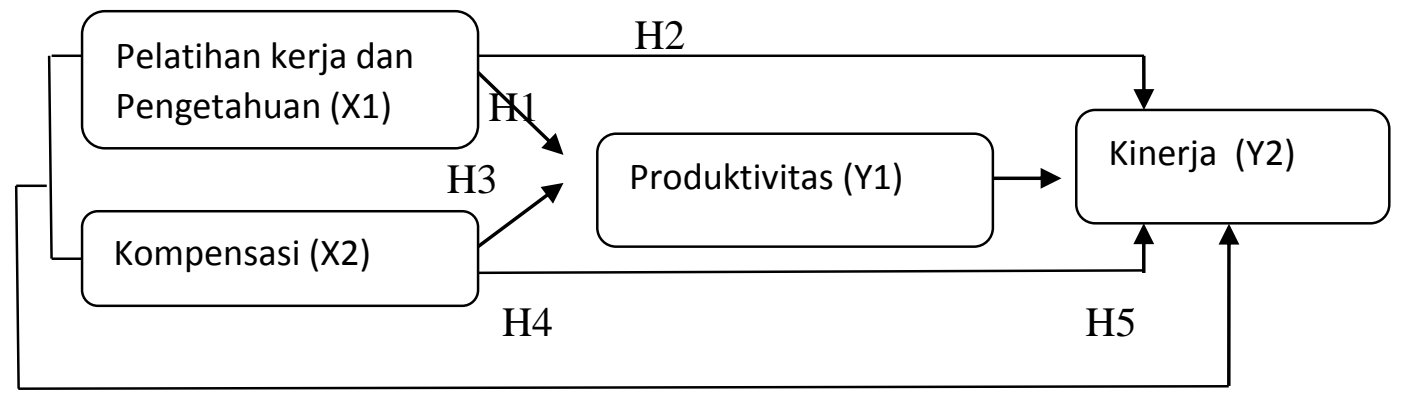

\section{Hasil dan Pembahasan}

a. Hasil Uji Model Teoritis

Berdasarkan model teoritis yang dibangun dalam penelitian ini diajukan model empiris yang disajikan pada Gambar dibawah ini

Gambar .2. Model Structural Equation Modelling (SEM)

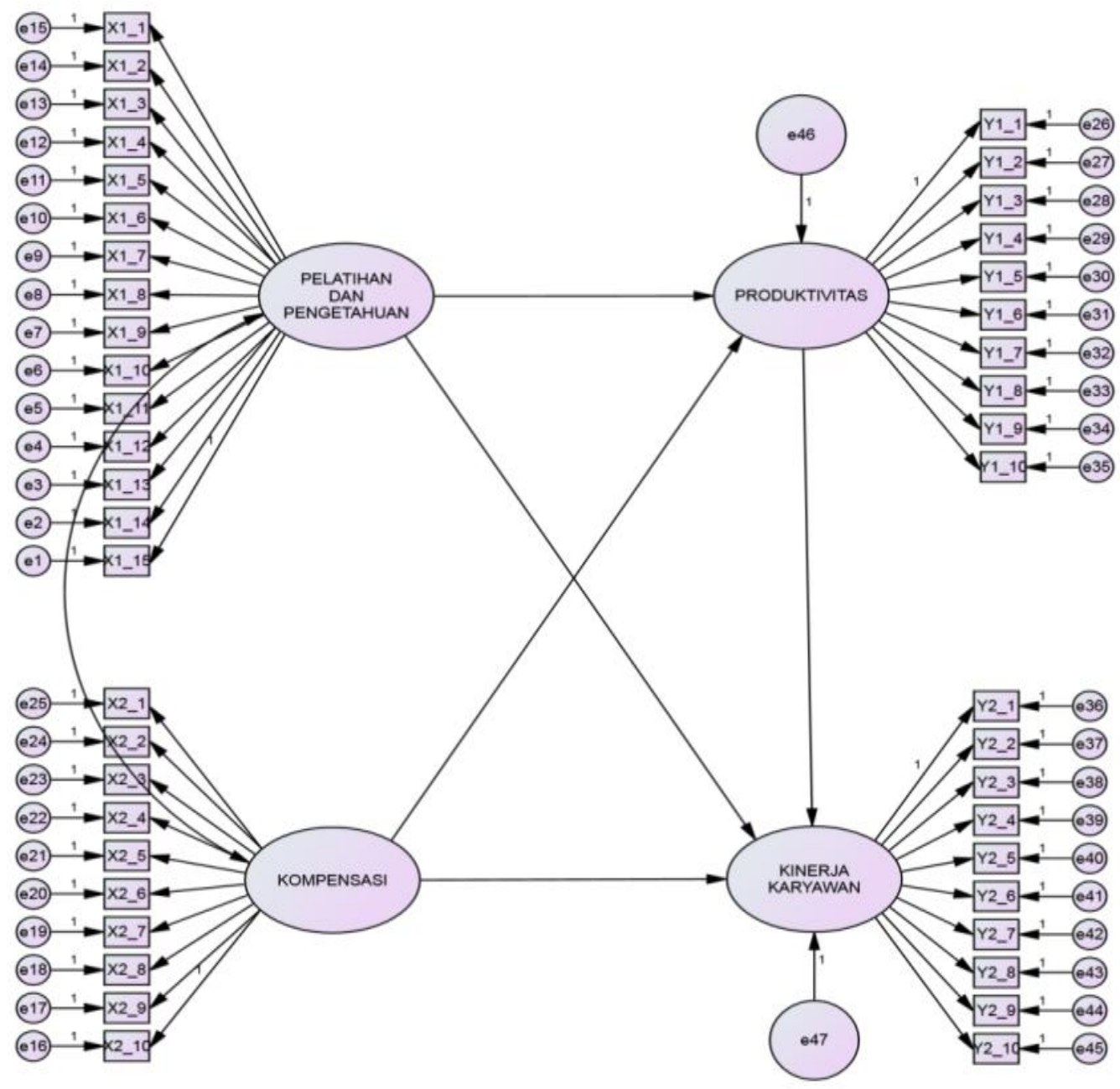

Sumber : Hasil Pengolahan Data 
Model struktural pada Gambar 3 digunakan sebagai dasar menguji pengaruh Pelatihan dan Pengetahuan (X1), Kompensasi (X2) terhadap Produktivitas (Y1) serta dampaknya terhadap Kinerja Karyawan (Y2).

Gambar 3. Permodelan Structural Equation Modelling (SEM)

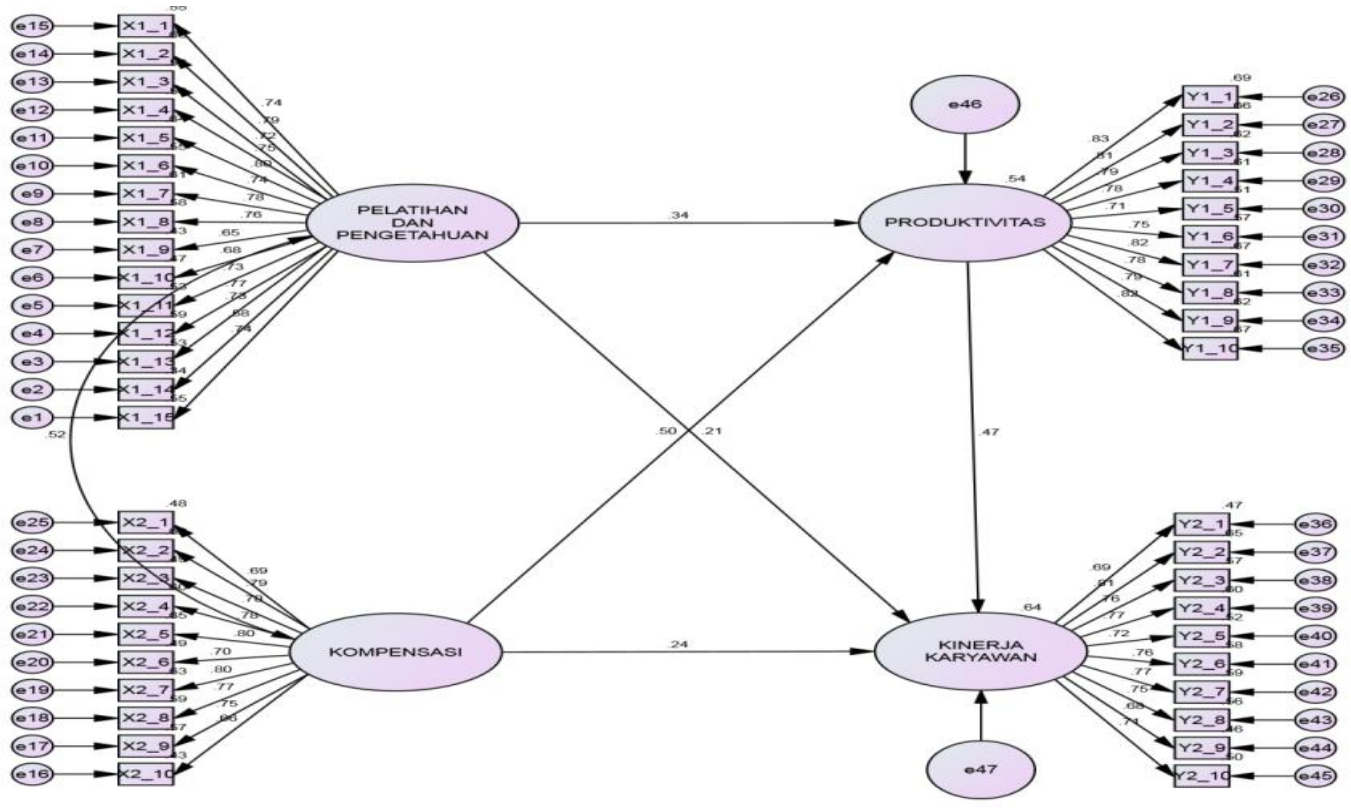

Sumber : Hasil Pengolahan Data

\section{b. Estimasi Parameter dan Uji Signifikansi Path}

Menguji hipotesis yang diajukan, dapat dilihat nilai t-statistik setelah dilakukan pengolahan data. Batas untuk menolak dan menerima hipotesis yang diajukan adalah apabila nilai $\mathrm{t}$ melebihi nilai t-tabel $(\alpha=0,05)$ sebesar 1,96 dan kesesuaian pengaruh hipotesis (negatif atau positif), maka hipotesis akan diterima atau menolak hipotesis nol (Ho). Hasil estimasi statistik dapat dilihat seperti pada Tabel 4, di bawah ini:

Tabel 4. Estimasi Parameter dan Uji Signifikansi Path

\begin{tabular}{|lll|ccccc|}
\hline & & & Estimate & S.E. & C.R. & \multicolumn{1}{l|}{ P } & Label \\
\hline Produktivitas & $<---$ & Pelatihan_dan_Pengetahuan & .441 & .138 & 3.203 & .001 & par_19 \\
Produktivitas & $<---$ & Kompensasi & .373 & .088 & 4.233 & $* * *$ & par_21 \\
Kinerja_Karyawan & $<---$ & Pelatihan_dan_Pengetahuan & .236 & .118 & 2.002 & .045 & par_20 \\
Kinerja_Karyawan & $<---$ & Kompensasi & .161 & .080 & 2.007 & .045 & par_22 \\
Kinerja_Karyawan & $<---$ & Produktivitas & .620 & .118 & 5.242 & $* * *$ & par_23 \\
\hline
\end{tabular}

Sumber : Hasil Pengolahan Data

\section{c. Pembahasan Hasil Penelitian \\ Pengaruh antar variabel}

Hipotesis pertama (Variabel X1 terhadap Y1)

Hasil uji terhadap koefisien parameter antara Pelatihan dan Pengetahuan (X1) terhadap Produktivitas (Y1) menunjukkan pengaruh positif sebesar 0,441 (yaitu berdasarkan nilai 
original sample $\mathrm{X} 1 \rightarrow \mathrm{Y} 1$ dengan nilai $\mathrm{P}$-value $=0,001)$ dan signifikan pada $(\alpha=0,05)$ dengan nilai statistik C.R. sebesar 3,203 (diatas 1,96). Hasil uji ini menyimpulkan Pelatihan dan Pengetahuan (X1) memiliki pengaruh yang signifikan terhadap Produktivitas (Y1).

\section{Hipotesis kedua (Pengaruh variabel X1 terhadap Y2)}

Hasil uji terhadap koefisien parameter antara Pelatihan dan Pengetahuan (X1) terhadap Kinerja Karyawan (Y2) menunjukkan pengaruh positif sebesar 0,236 (yaitu berdasarkan nilai original sample $\mathrm{X} 1 \rightarrow \mathrm{Y} 2$ dengan nilai $\mathrm{P}$-value $=0,045)$ dan signifikan pada $(\alpha=0,05)$ dengan nilai statistik C.R. sebesar 2,002 (diatas 1,96). Hasil uji ini menyimpulkan Pelatihan dan Pengetahuan (X1) memiliki pengaruh yang positif dan signifikan terhadap Kinerja Karyawan (Y2).

\section{Hipotesis ketiga (Pengaruh variabel X2 terhadap Y1)}

Hasil uji terhadap koefisien parameter antara Kompensasi (X2) terhadap Produktivitas (Y1) menunjukkan pengaruh positif sebesar 0,373 (yaitu berdasarkan nilai original sample $\mathrm{X} 2 \rightarrow$ Y1 dengan nilai P-value $=0,000)$ dan signifikan pada $(\alpha=0,05)$ dengan nilai statistik C.R. sebesar 4,233 (diatas 1,96). Dapat disimpulkan Kompensasi (X2) memiliki pengaruh positif dan signifikan terhadap Produktivitas (Y1).

\section{Hipotesis empat (Pengaruh variabel X2 terhadap Y2)}

Hasil uji terhadap koefisien parameter antara Kompensasi (X2) terhadap Kinerja Karyawan (Y2) menunjukkan pengaruh positif sebesar 0,161 (yaitu berdasarkan nilai original sample $\mathrm{X} 2 \rightarrow \mathrm{Y} 2$ dengan nilai P-value $=0,045)$ dan signifikan pada $(\alpha=0,05)$ dengan nilai statistik C.R. sebesar 2,007 (diatas 1,96). Dapat disimpulkan Kompensasi (X2) memiliki pengaruh positif dan signifikan terhadap Kinerja Karyawan (Y2).

\section{Hipotesis kelima (Pengaruh variabel Y1 terhadap Y2)}

Hasil uji terhadap koefisien parameter antara Produktivitas (Y1) terhadap Kinerja (Y2) menunjukkan pengaruh positif sebesar 0,620 (yaitu berdasarkan nilai original sample $\mathrm{Y} 1 \rightarrow$ Y2 dengan nilai P-value $=0,000)$ dan signifikan pada $(\alpha=0,05)$ dengan nilai statistik C.R. sebesar 5,242 (diatas 1,96). Dapat disimpulkan Produktivitas (Y1) memiliki pengaruh positif dan signifikan terhadap Kinerja Karyawan (Y2).

\section{Pengaruh Langsung dan Tidak Langsung \\ Pengaruh Langsung (direct effect)}

Tabel 5. Pengaruh Langsung

\begin{tabular}{|l|cccc|}
\hline & Kompensasi & $\begin{array}{c}\text { Pelatihan } \\
\text { \& Pengetahuan }\end{array}$ & Produktivitas & $\begin{array}{c}\text { Kinerja } \\
\text { Karyawan }\end{array}$ \\
\hline Produktivitas & .373 & .441 & .000 & .000 \\
Kinerja_Karyawan & .161 & .236 & .620 & .000 \\
\hline
\end{tabular}

Sumber : Hasil Pengolahan Data

Dari hasil tabel di atas, bahwa Pelatihan dan Pengetahuan (X1) dan Kompensasi (X2) mempunyai pengaruh langsung terhadap Produktivitas (Y1) sebesar X1 = 0,441, X2 = 0,373. Pelatihan dan Pengetahuan (X1), Kompensasi (X2) dan Produktivitas (Y1) mempunyai pengaruh langsung terhadap Kinerja Karyawan (Y2) sebesar X1 = 0,236, X2 = 0,161 , dan $\mathrm{Y} 1=0,620$. 


\section{Pengaruh Tidak Langsung (indirect effect)}

Tabel 6. Pengaruh Tidak Langsung

\begin{tabular}{|l|cccc|}
\hline & Kompensasi & $\begin{array}{c}\text { Pelatihan } \\
\text { \& Pengetahuan }\end{array}$ & Produktivitas & $\begin{array}{c}\text { Kinerja } \\
\text { Karyawan }\end{array}$ \\
\hline Produktivitas & .000 & .000 & .000 & .000 \\
Kinerja_Karyawan & .231 & .273 & .000 & .000 \\
\hline
\end{tabular}

Sumber : Hasil Pengolahan Data

Dari hasil perhitungan diatas terlihat bahwa, Pelatihan dan Pengetahuan (X1) mempunyai pengaruh tidak langsung terhadap terhadap Kinerja Karyawan (Y2) melalui Produktivitas (Y1) sebesar 0,273. Kompensasi (X2) mempunyai pengaruh tidak langsung terhadap terhadap Kinerja Karyawan (Y2) melalui Produktivitas (Y1) sebesar 0,231.

\section{Pengaruh Total (Total effect)}

Tabel 7. Pengaruh Total

\begin{tabular}{|l|cccc|}
\hline & Kompensasi & $\begin{array}{c}\text { Pelatihan } \\
\text { \&Pengetahuan }\end{array}$ & Produktivitas & $\begin{array}{c}\text { Kinerja } \\
\text { Karyawan }\end{array}$ \\
\hline Produktivitas & .373 & .441 & .000 & .000 \\
Kinerja_Karyawan & .392 & .509 & .620 & .000 \\
\hline
\end{tabular}

Sumber : Hasil Pengolahan Data

Dari hasil perhitungan terlihat diatas bahwa Pelatihan dan Pengetahuan (X1), Kompensasi (X2) mempunyai total pengaruh terhadap Produktivitas (Y1) sebesar X1 = 0,441, X2 = 0,373. Sedangkan Pelatihan dan Pengetahuan (X1), Kompensasi (X2) dan Produktivitas (Y1) mempunyai total pengaruhg terhadap Kinerja Karyawan (Y2) sebesar $\mathrm{X} 1=0,509, \mathrm{X} 2=0,391$ dan $\mathrm{Y} 1=0,620$.

\section{Simpulan}

Pelatihan dan Pengetahuan memiliki pengaruh yang signifikan terhadap Produktivitas, Pelatihan dan Pengetahuan memiliki pengaruh yang positif dan signifikan terhadap Kinerja Karyawan, Kompensasi memiliki pengaruh positif dan signifikan terhadap Produktivitas, Kompensasi memiliki pengaruh positif dan signifikan terhadap Kinerja Karyawan, Produktivitas memiliki pengaruh positif dan signifikan terhadap Kinerja Karyawan.

\section{Daftar Pustaka}

Andri Pettarani (2018) pengaruh pelatihan kerja terhadap produktivitas kerja karyawan Jurnal Bussines Economic. Sumber: http://ejournalfia.ub.ac.id//Anwar.syaiful// Anwar Prabu Mangkunegra (2015). Manajemen Sumber Daya Manusia. Bandung. Penerbit : Remaja Rodaskarya

Aliya, S., \& Tobari, T. (2019) Pengaruh Pendidikan dan Pelatihan Terhadap Produktivitas Kerja Karyawan Bagian Produksi Pada PT. Semen Baturaja (Persero) Tbk Palembang. Jurnal Manajemen, Kepemimpinan, dan Supervisi Pendidikan, Volume 4, No.1, 97-103. 
Apriani, D., \& Aliya, S. (2019) Pengaruh Disiplin Kerja dan Pelatihan Kerja Terhadap Prestasi Kerja Karyawan pada PT. Sriwijaya Palm Oil Grup Palembang. Prosiding Seminar Nasional Ekonomi dan Bisnis Global Competitive Advantage, Palembang: 3 Oktober 2019. Hal. 530-538.

Edy Sutrisno. (2015). Manajemen Sumber Daya Manusia. Jakarta : Kencana Prenada Media Grup Kasmir (2018). Manajemen Sumber Daya Manusia. Depok: Rajawali Pers

Lucky Adrian Wibowo (2017), Pengaruh Pelatihan Kerja Dan Kompensasi Terhadap Kinerja Karyawan Perusahaan Daerah Air Minum Tirta Bhagasasi.Jurnal Bussines Economic.Sumber :http://ejournalfia.ub.ac.id// lucky.adria. wibowo/ pelit bangsabekasi

Malayu Hasibuan S.P. (2012) Manajemen Sumber Daya Manusia. Jakarta : Bumi Askara M. Phill, Wibowo. (2016). Manajemen Kinerja, Edisi Ke lima. Jakarta : PT. Raja Grafindo Persada

Mondy, R Wayne. (2008). Manajemen Sumber Daya Manusia Jakarta : Penerbit Erlangga.

Nizar (2015) pengaruh pelatihan terhadap kinerja karyawan. Bussines Economic.Sumber :http://ejournalfia.ub.ac.id// Niizar/ pelit bangsabekasi

Pandi Afandi. (2018). Manajemen Sumber Daya Manusia. Jakarta Penerbit :The Publish

Risha Faiq Fakhri (2015) ,Pengaruh Kompensasi Dan Pelatihan Terhadap Kinerja Karyawan dan Kepuasan Kerja Pada Pt. Audio Sumitomo Technology. Jurnal Bussines Economic, Sumber: http://ejournalfia.ub.ac.id/index.php/profit/article/view/305/562

Sugiyono,(2010) Metode Penelitian Kuantitatif Kualitatiif \& RND Bandung : Alfabeta

Sugiyono, (2016) Metode Penelitian Kuantitatif Kualitatiif \& RND Bandung : Alfabeta

Syaiful Anwar (2016), Pengaruh Pelatihan Kerja, Pengalaman Kerja dan Kompensasi Terhadap Produktivitas Kerja Karyawan Unit Produksi Pada PT. Misaja Mitra Pati Factory Kabupaten Pati. Jurnal Bussines Economic.Sumber : http://ejournalfia.ub.ac.id//Anwar.syaiful//

W Allimudin (2012) pengaruh karyawan kinerja karyawan Unit Produksi Pada PT. Mitra sahaja. Jurnal Bussines Economic.Sumber :http://ejournalfia.ub.ac.id//Anwar.syaiful//

\section{Copyright Disclaimer}

Copyright for this article is retained by the author(s), with first publication rights granted to the journal. 